\title{
Peer review in writing activities: outcomes and perceptions of EFL students
}

\author{
Theresia Adventris Ndohna Ruru, ${ }^{1}$ Teguh Sulistyo ${ }^{2}$ \\ 1,2English Language Department, Universitas Kanjuruhan Malang, Indonesia \\ 1ndohnaruru30@gmail.com, 22sulistyoteguh@unikama.ac.id \\ *) correspondence: sulistyoteguh@unikama.ac.id
}

\begin{abstract}
This study aims at investigating the effect of peer review on students' writing ability and the students' perceptions toward the use of peer review technique in writing class. This is an experimental research by involving 62 EFL students of eighth graders of a Junior High School in Malang, Indonesia. The data were obtained by conducting a writing (pre-test an post-test) and giving questionnaire. The data were analyzed by using quantitative descriptive statistics. The qualitative data expressed descriptively about students perceptions toward using peer review technique in writing acitvity. The findings show that the students in experimental group who were taught by using peer review technique got better achievement in writing ability than the students in control group who were taught by using selfassessment strategy. The use of peer review technique in writing class makes the class less anxious and more enjoyable. The students are enthusiastic so that the class become more student-centered. The students are able to interact each other in giving comments and suggestions to reduce mistakes in terms of global and local issues to make better subsequent of writing product. In addition, the result of questionnaire shows that the students have positive attitudes toward the use peer review technique in writing class.
\end{abstract}

Keywords: effect, peer review, writing ability

\section{INTRODUCTION}

Writing is one of four basic skills in English for the foreign language learners that should be learnt well. Writing is one of challenging productive skills especially for English Foreign Learners. According to Megaib (2014), the challenge in teaching writing is the students' mother tongue has influenced a lot in the production of the students' writing. Ariyanti (2016) found the biggest challenge is the difference in cultural background between students' mother tongue and English so that their production of writing does not sound well in appropriate culture of English. Writing is also difficult to be mastered in terms of local and global issues. Local issues consist of vocabulary, grammar, and mechanic whereas global issues consist of content and organization. Most of Indonesian students face challenges regarding to grammatical structures in English and delivering the content of their writing composition (Ariyanti, 2016).

Considering writing as a complicated skill to be mastered, feedback is one of the ways which is the important thing in the reviewing process in improving students' writing ability. Writing feedback is very useful for students to help them improving their writing becomes good quality. According to Richards and Schmidt in Megaib (2014) Feedback refers to comments, explanations and helpful data which learners receive either from the teacher or other people. Writing feedback is very important for English as Foreign Language students because it plays a central role in writing process to fulfill the aim of writing class (Ghanbari, 2015).There are two different ways of giving students feedback on their written work. Those are teacher and peer feedback. Teacher feedback can be defined as a process through which a teacher communicates with students about how they responded to a task, while peer feedback is the use of learners as sources of information for each other in such a way that learners assume roles and responsibilities normally taken on by a formally trained teacher, tutor, or editor in 
commenting on and critiquing catch other's drafts in both written and oral formats in the process of writing (Hansen \& Liu, 2005).

Theoretically, there are some advantages of peer review on students' writing ability. Peer review can be an effective technique of revision for students to improve their writing and critical thinking skills. Moreover, involving students in the process of peer review enables them to interact with each other as writers and readers and helps them to write more confidently and with lower levels of anxiety (Moussaoui, 2012). Correcting mistakes by peers does not only enable students to be more aware of their peers' mistakes, but it also promotes their level in academic writing in general (Itmeizeh, 2016). By applying peer review, students know the motivation for wanting to help one another improve (Jahin, 2012). Peer feedback on writing encouraged the learners to expand their knowledge through facing situations which provide them with opportunities to rely on themselves to think critically and improve their autonomy (Ghanbari, 2015).

In relation to the result of studies deals with peer review whether peer review is effective or not, there are some studies show positive results on students' writing ability. Peer review technique has a positive effect on students' writing ability. By having peer review, students take on new roles that eventually help them to be more actively involved in their own writing process (Sotoudehnama, 2016). Moussaoui (2012) in the investigation states that peer review is an effective technique of revision for student writers to improve their writing. Thus, as readers, students can enhance their critical reading skills by reviewing their peers' writing and, as writers; they foster their critical thinking by revising their own pieces of writing after getting peer feedback. Peer review affects students' writing ability. Students have profited from this technique to reduce mistakes in their writing composition and they become more enjoyable and interested in writing (Itmeizeh, 2016). Jahin (2012) in the investigation indicated that peer review had a positive effect on developing participants' essay writing ability and students are motivated for wanting to help one another improve their writing. Peer review has a significant effect on improving learners' writing ability to make better subsequent drafts (Ghanei, 2015). Like other studies, there are still some studies revealed that peer review has significant effect on learners' writing ability (Kustati, 2014);(Nguyen, 2016);(Bijami, 2013); (Ghanbari, 2015). In addition, peer review contributes positively toward students' writing anxiety which makes the learning environment less anxious and stressful and increases their confidence. The use of peer feedback in writing classes reduced students' writing anxiety in terms of cognitive, somatic, and avoidance anxiety (Yastibas, 2015).

In contrast, there are some previous studies that remain unclear, indicating the discrepancies revealed the studies have different findings. A study by Maarof (2011) indicated that the students perceived the role of feedback to be less facilitative in enhancing their ESL writing. They had mixed perceptions on the reliability of peer feedback. The students appeared to regard their peer as having an equal status with them and that their peers are less proficient in providing feedback compared to their teachers. Most of the students thought their peers do not often point out or correct all mistakes when giving written feedback compared to their teachers. Another study by Suba (2014) indicated that peer review is not effective to be applied because the students are not accustomed to using this technique due to the learning process is still oriented to teacher-centered. Generally peer review affects positively to the process of learning especially upon students' with low anxiety, but not to the students' with high anxiety (Suparma, 2013). A study by Astrid Annisa, et al. (2017) indicated that peer feedback was effective for students having low writing anxiety but not for high writing anxiety students.

Because of those inconsistent findings, the present study then aims at investigating further the effect of peer review on student's writing ability to reveal further information. This study focuses on using peer review as a teaching tool in order to improve students' writing ability especially in global (content and organization), local issues (vocabulary, grammar, and mechanic) and students'perceptions toward the use of peer review technique in writing class. In this case, the researcher focuses on investigating the effect of peer review on students' descriptive writing task. Hopefully, this research provides addition information about the effect of peer review on students' 
writing ability which concern in global issues (content and organization) and local issues (grammar, vocabulary, and mechanics)

\section{METHODS}

This study was designed using experimental research since it aimed at investigating the effect of peer review (independent variable) on students' writing ability (dependent variable), so there were two groups: experimental and control groups. The data were qualitative and quantitative data. The qualitative data were analyzed by transcribing, analyzing, and interpreting the data. There were 62 students of eighth grade as the participants. 31 students of class A become control group while 31 students of class B become experimental group. The researcher used two main instruments in order to get the quantitative and qualitative data, such as test (pre-test amd post-test) and questionnaire which consisted of 10 items.

There were several activities in this research, such as pre-test, treatments, and post-test. The activities were done in six meetings. The pre-test was given in the first meeting and the treatments conducted in the second until fifth meetings. In experimental group, the reseacher taught writing a descriptive paragraph by using peer review while in the control group, the researcher taught the students by using self-assessment strategy. After the treatment was given, The researcher gave the post-test in the sixth meeting.

\section{RESULTS AND DISCUSSION}

This part presents the effect of peer review on students' writing ability and the students' perceptions towards this strategy.

\section{The effects of Peer Review on Students' Writing Ability}

The result of $\mathrm{t}$-test computation answered the research questions of the study.

TABLE 1. Independent Sample t-test for Experimental Group and Control Group Independent Samples Test

\begin{tabular}{|c|c|c|c|c|c|c|c|c|c|c|}
\hline & & \multicolumn{2}{|c|}{$\begin{array}{c}\text { Levene's Test } \\
\text { for Equality of } \\
\text { Variances }\end{array}$} & \multicolumn{7}{|c|}{ t-test for Equality of Means } \\
\hline & & \multirow[t]{2}{*}{$\mathrm{F}$} & \multirow[t]{2}{*}{ Sig. } & \multirow[t]{2}{*}{$\mathrm{T}$} & \multirow[t]{2}{*}{ df } & \multirow{2}{*}{$\begin{array}{l}\text { Sig. } \\
(2- \\
\text { tailed } \\
\quad)\end{array}$} & \multirow[t]{2}{*}{$\begin{array}{c}\text { Mean } \\
\text { Differen } \\
\text { ce }\end{array}$} & \multirow[t]{2}{*}{$\begin{array}{l}\text { Std. Error } \\
\text { Difference }\end{array}$} & \multicolumn{2}{|c|}{$\begin{array}{c}95 \% \text { Confidence } \\
\text { Interval of the } \\
\text { Difference }\end{array}$} \\
\hline & & & & & & & & & Lower & Upper \\
\hline \multirow[b]{2}{*}{ Score } & $\begin{array}{c}\text { Equal } \\
\text { variances } \\
\text { assumed }\end{array}$ & 1.594 & .212 & 3.930 & 60 & .000 & 4.677 & 1.190 & 2.297 & 7.058 \\
\hline & $\begin{array}{c}\text { Equal } \\
\text { variances } \\
\text { not } \\
\text { assumed }\end{array}$ & & & 3.930 & 59.748 & .000 & 4.677 & 1.190 & 2.297 & 7.058 \\
\hline
\end{tabular}

Table 1 shows that the difference of mean score was 4.677 with standard error difference 2.297. Alternative hypothesis (Ha) is accepted if the level of significant $<0.05$ and null hypothesis (Ho) is accepted if the level of significant $>0.05$. The level of significant was lower than the value of probability $0.05(0.00<0.05)$, the alternative hypothesis was accepted. The probability (p) was less than 0.05 , it was .000 . It means that there was a significant difference of using peer review technique on students' writing abiltiy. The researcher concluded that peer review technique was an effective way to be applied. 


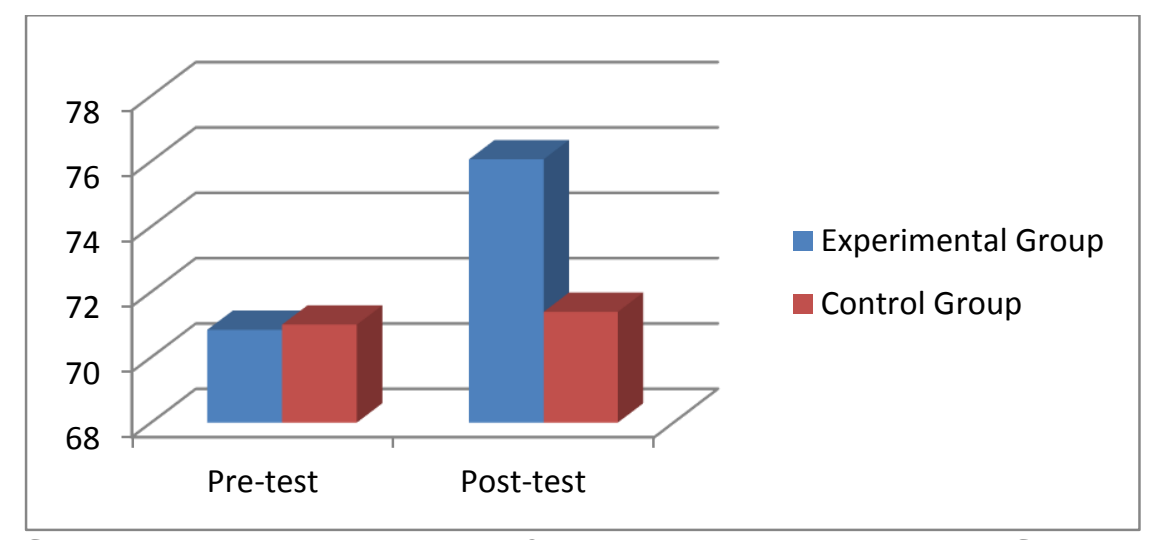

Figure 1. The Comparison Post-test Mean Score of Experimental and Control Group

Figure 1 shows that in the pre-test, the mean score of both groups were not too far different. The mean score of experimental group was 70.84 and the control group was 71.00 , but in the posttest after giving different treatment, such as peer review technique for experimental group and selfassessment for control group, the mean score of both goups were strongly different. The experimental group got greater mean score than control group. The mean score of experimental group was 76.06 while the mean score gained by the control group was 71.39. In brief, The improving of students' score in experimental group were greater than the students in control group. It can be seen by the improving of the students score which was 5.22 while the students in control group was 0.39 .

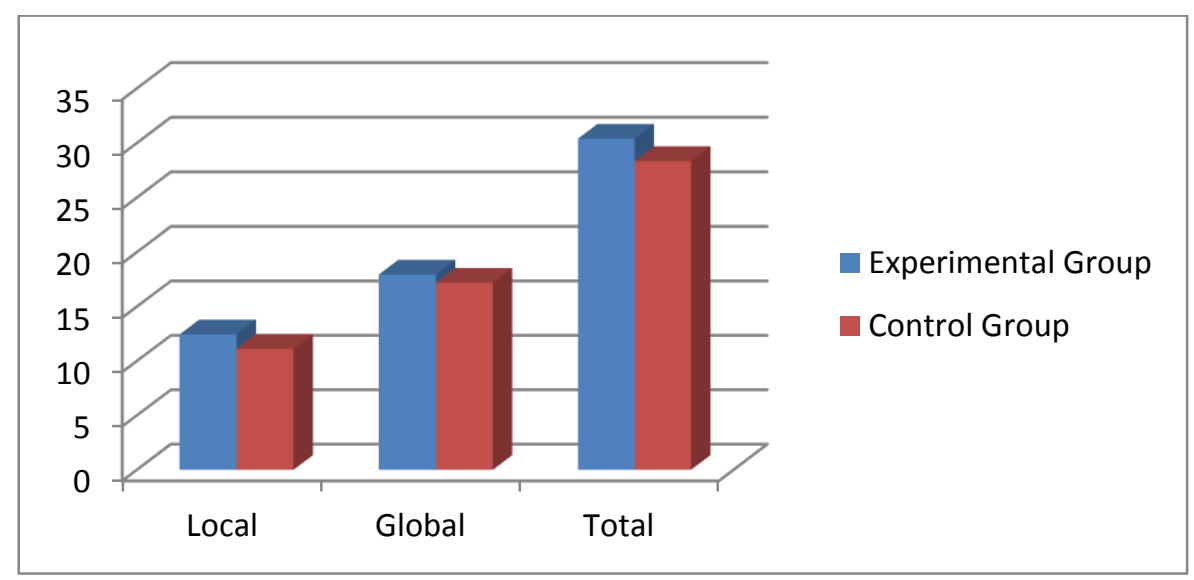

Figure 2. The Comparison of the Means from the Writing Test in Terms of Local and Global Issues in Experimental and Control Group

Based on Figure 2, the results show that there were difference means between students' in experimental and control groups in terms of local (grammar, vocbulary and mechanics) and global (content and organization) issues. In terms of local issue, the students' in experimental group got means 12.45. While the students in control group gained 11.13. In terms of global issue the students in experimental group gained 17.95 and the students in control group got 17.21. The total average of global and local issues of students in experimental group was 30.4. While the total of global and local issues of students in control group was 28.34. It can be concluded that there were difference between the means of students' score in global and local issues. 
Students' Perceptions towards the Implementation of Peer Review Strategy in Writing Class According to the result of questionnaire, students had a possitve point of view towards the implementation of per review technique in writing class. They agree that peer review technique help them to improve their writing ability. According to most of the students, receiving and giving feedback to their friends decrease their anxiety in writing. They know that making mistakes is a part of learning and they make some common mistakes. Receiving and giving feedback to their classmates may increase their confidence in writing so that they feel less anxious and stressed while writing something in English (Yastibas, 2015). A study by Miftah (2016), most of the students considered peer review technique as educational and supportive. Most of the students have positive attitude towards the application of peer review technique in writing class. They appreciate their friends' correction on their writing and they enjoy the process of writing. In line with study by Itmeizeh (2016), students are enthusiatic in the process of writing. They like to colaborate each other to make their writing become better subsequent. The existence of peer review technique in the process of revising make the condition of the clasroom become less anxious and stressfull.

\section{CONCLUSION}

Based on the reseach questions, there are two conclusions made in this research. Firstly, peer review technique has a siginificant impact on students' writing ability in terms of global (content and organization) and local issues (grammar, vocabulary and mechanics) in the context of writing a descriptive paragraph. The implementation of peer review in writing class creates the condition of the class become less anxious and more enjoyable. The students are enthusiastic and the teaching learning process become more student-centered.

By the existing of peer review technique in the process of writing, the students are able to interact each other in giving comments and suggestions to reduce errors in terms of global (content and organization) and local (grammar, vocabulary, and mechanic) issues to make better subsequent of writing product. They are responsible for their own writing activities. Overall, the students writing' ability are improved, but not at all of the aspects in terms of global and local issues, such as grammar and vocabulary because mostly the students still got difficulties in those aspects. There were only some students who got better achievement in the aspects of grammar and vocabulary. It is hard for them to write a text with correct grammar and effective choice of words and word form because they are not accustomed to writing in English. Teacher should pay attention more on the way to teach students about grammar and also creates activities to enhance students' vocabulary.

Second, students have positive responses toward the use of peer review in the writing class. Majority of the students agree with the implementation of the peer review technique in writing class. The writing activities become more interesting and the students are motivated in writing descriptive paragraph. They can explore their ideas in written form. They become aware of the mistakes that they make in their writing and they are really enjoy the process of writing. In adition they are more confident in writing class. In conclusion, peer review can be used in writing class in order to improve sstudents writing ability.

\section{REFERENCES}

Ariyanti. 2016. The teaching of EFL writing in Indonesia. Dinamika Ilmu, 16(2), 263-277.

Astrid Annisa, et al. 2017. The effect of writing feedback techniques and students 'writing anxiety on students' essay writing ability. International Journal of Foreign Language Teaching \& Research, 5(18).

Bijami, M. 2013. Peer feedback in learning English writing: advantages and disadvantages. Journal of Studies in Education, 3(4), 91-97. https://doi.org/10.5296/jse.v3i4.4314

Carmines \& Zeller (1979). Reliability and validity assessment. In Reliability and validity assessment (pp. 17-26). The International Professional Publishers Newbury Park London New Delhi.

Dantes. 2013. The investigation of the teaching of writing at the tenth grade of senior high school (SMAN) 1 Aikmel in Lombok. E-Journal Program Pascasarjana Universitas Pendidikan Gajayana, 1. 
Ruru, T. A. N., Sulistyo, T.

Fadhilah. 2017. The effectiveness of written "peer review” towards English 3 students' writing skill. Jurnal Vision, 6(1), 87-106.

Ghanbari. 2015. An exploration of the effect of time pressure and peer feedback on the Iranian EFL students $\hat{a}^{\mathrm{tm}}$ writing performance. Theory and Practice in Language Studies, 5(11), 2251-2261.

Ghanei. 2015. The effect of peer review on cohesion improvement in writing skill among EFL learners. International Journal of Language Learning and Applied Linguistics World, 8(2), 103-112.

Hansen \& Liu. 2005. Guiding principles for effective peer response. ELT Journal, 59(1), 31-38. https://doi.org/10.1093/elt/cci004

Itmeizeh, M. J. 2016. Impact of peer correction on reducing English language students' mistakes in their written essays in pauc and learners' attitudes towards this technique. Theory and Practice in Language Studies, 6(11), 2068-2078.

Jahin, H. J. 2012. The effect of peer reviewing on writing apprehension and essay writing ability of prospective EFL teachers. Australian Journal of Teacher Education, 37(11).

Kustati, M. 2005. The effect of the peer-review technique on students' writing ability, 71-81.

Maarof. 2011. Role of teacher, peer and teacher-peer feedback in enhancing ESL students' writing. World Applied Sciences Journal, 15, 29-35.

Megaiab. 2014. The English writing competence of the students of Indonesian senior high school. WEI International Academic Conference Proceedings, (2000), 187-192.

Miftah. 2016. EFL students' performance and expectation towards peer response in writing classroom. Indonesian Journal of English Education, 3(2), 208-223. https://doi.org/10.15408/ijee.v3i2.5513.Permalink/

Moussaoui. 2012. An investigation of the effects of peer evaluation in enhancing Algerian students' writing autonomy and positive affect. International Conference on Education and Educational Psychology, 69, 1775-1784. https://doi.org/10.1016/j.sbspro.2012.12.127

Nguyen. 2016. Peer feedback practice in EFL tertiary writing classes. English Language Teaching, 9(6), 76-91. https://doi.org/10.5539/elt.v9n6p76

Sotoudehnama. 2016. The impact of peer review on EFL learners' writing proficiency : global and local aspects. In Porta Linguarium (pp. 35-47).

Suba. 2014. What are the effects of written peer feedback training on turkish ELT students' writing quality ?. International Journal of Arts and Commerce, 3(9), 1-15.

Sugiyono. 2007. Metode Penelitian Kuantitatif Kualitatif dan R\&D. Bandung: Alfabeta.

Suparma. 2013. The effect of peer assessment and anxiety on writing competency of grade $x$ students of SMA Negeri 5 Denpansar. E-Journal Program Pascasarjana Universitas Pendidikan Ganesha, 1.

Yastibas. 2015. The effect of peer feedback on writing anxiety in Turkish EFL (English as a foreign language) students. An International Conference on Teaching and Learning English as an Additional Language, 199, 530-538. https://doi.org/10.1016/j.sbspro.2015.07.543 